\title{
PERSEPSI MASYARAKAT TERHADAP HIDROPONIK DI KELURAHAN TELING BAWAH, KOTA MANADO
}

\author{
Mercy Y. Sengkey \\ Welson M. Wangke \\ Elsje P. Manginsela
}

\begin{abstract}
ABSRACT
This study aimed to analyze and determine the public perception of hydroponic in the distict Teling Bawah Manado City. This aims was conducted over five months from November 2016 to the month of Maret 2017 from preparation to the arrangement of research reports. The location of research is in districts Teling Bawah Manado City. This research uses primary data and secondary data. Primary data was obtained from 30 respondents using questionnaires, while secondary data obtained from the office district Teling Bawah Manado City. The sampling method in this study was used purposive sampling method. Result of this research show that the public percepstion of Hydroponic are very good with the index of perceptions $84,16 \%$ and are classified to category of strongly agree. The society are strongly agree with the existance of agriculture technique using Hydroponic. People think that Hydroponic is very useful for the society, because with Hydroponic, people could consume healthy fruits and vegetables without using chemis chemical products; no need to try very hard to find a land to cultivate; could take advantages of used goods at home; no need a long time to use hydroponic; and use soil as conventional agriculture, so that the actors of Hydroponic do not have to be in contact with worms.
\end{abstract}

Keywords: Perception, Society, Hydroponics, Teling Bawah Village, Manado City

\begin{abstract}
ABSTRAK
Penelitian ini bertujuan untuk mengetahui Persepsi Masyarakat Terhadap Hidroponik Di Kelurahan Teling Bawah Kota Manado. Penelitian ini dilaksanakan selama lima bulan yaitu dari bulan November 2016 sampai dengan bulan Maret tahun 2017, mulai dari persiapan sampai penyusunan laporan penelitian. Tempat penelitian adalah Kelurahan Teling Bawah Kota Manado. Penelitian ini menggunakan data primer dan data sekunder. Data primer diperoleh dari 30 responden dengan menggunakan kuesioner. Sedangkan data sekunder diperoleh dari kantor Kelurahan Teling Bawah Kota Manado. Metode pengambilan sampel dalam penelitian ini menggunakan metode purposive sampling. Hasil Penelitian menunjukkan bahwa persepsi masyarakat terhadap Hidroponik sangat baik dengan indeks persepsi 84,16\% dan tergolong dalam kategori sangat setuju. Masyarakat sangat setuju dengan adanya teknik pertanian dengan menggunakan Hidroponik, masyarakat berpendapat bahwa Hidroponik sangat bermanfaat bagi masyarakat karena dengan Hidroponik masyarakat dapat mengkonsumsi buah dan sayur yang sehat tanpa menggunakan produk-produk kimia, tidak perlu bersusah payah mencari lahan untuk bercocok tanam,dapat memanfaatkan barang-barang bekas di rumah, tidak membutuhkan waktu yang lama untuk berhidroponik, dan tidak menggunakan tanah seperti pertanian konvensional sehingga pelaku Hidroponik tidak perlu bersentuhan dengan cacing.
\end{abstract}

Kata kunci: Persepsi, Masyarakat, Hidroponik, Kelurahan Teling Bawah, Kota Manado 


\section{PENDAHULUAN}

\section{Latar Belakang}

Indonesia adalah negara agraris yang sebagian besar penduduknya memiliki mata pencaharian di bidang pertanian. Namun saat ini dunia pertanian di Indonesia menghadapi berbagai tantangan, antaralain, dengan semakin menyempitnya lahan pertanian. Di berbagai daerah, lahan pertanian dialih fungsikan menjadi lahan non-pertanian, antaralain berupa daerah industri dan pemukiman. Sementara kebutuhan akan hasil pertanian selalu bertumbuh setiap harinya sejalan dengan pertumbuhan penduduk. Selain itu, kendala lainnya adalah dunia pertanian konvensional atau pertanian yang menggunakan tanah atau hamparan lahan di hadapkan pada masalah kesuburan tanah. Petani kesulitan mendapatkan lahan subur yang semakin habis dikotori oleh polusi, baik itu berupa sampah maupun limbah cair, akibatnya produk hasil pertanian yang dihasilkan menjadi tidak sehat karena kebanyakann cenderung memakai produk kimia. Untuk itu, pemerintah mendorong urban farming yang bisa diartikan sebagai gerakan berkebun yang memaksimalkan lahan kota sebagai bagian dari basis ketahanan pangan (Widyawati, 2013). Pemerintah menggunakan lahan kota karena semakin berkurangnya lahan pertanian di desa-desa akibat peralihan alih fungsi lahan pertanian. Kota harus memiliki peran dalam produksi pertanian yaitu dengan program urban farming.

Kehidupan di perkotaan saat ini mulai semakin sesak karena pembangunan gedunggedung tinggi serta pembangunan perumahan. Setiap manusia beraktifitas di kota yang tampak hanyalah gedung-gedung yang tinggi, kendaraan yang semakin padat, dan rumah penduduk yang semakin padat. Tampaknya tidak ada kesejukan lagi bagi penduduk di Kota bahkan rindangnya pohon sudah tidak bisa dinikmati lagi karena kurangnya pemanfaatan lahan di sekitar pinggiran jalan dan di sekitar rumah penduduk untuk dijadikan sebuah kebun yang kecil. Lahan yang kosong cenderung dibuat bangunan daripada digunakan sebagai lahan yang kecil untuk bercocok tanam. Semakin hari, lahan tempat huni manusia semakin sempit, sehingga menyisakan sedikit ruang untuk bercocok tanam. Bercocok tanam merupakan kegiatan yang sangat menyenangkan, karena sebagian dari masyarakat yang tinggal di kota dapat menyalurkan hobinya serta menciptakan penghijauan seperti menanam tanaman penghias dan sayuran di pot-pot.

Pertanian Hidroponik merupakan respons dalam mengatasi masalah tersebut yang merupakan bagian dari urban farming. Sistem pertanian ini dapat di lakukan tanpa menggunakan lahan yang luas dan mudah dilakukan di pekarangan rumah saja. Hidroponik adalah sebuah cara bertani tanpa media tanah. Hidroponik merupakan sebuah teknologi bercocok tanam yang dapat menghasilkan bahan pangan (Suryani, 2016). Bertanam dengan hidroponik merupakan salah satu cara bertanam yang terbebas dari kendala seperti, kotor karena menggunakan tanah, berpanas-panasan, bahkan terbebas dari hama, antara lain, cacing dan ulat. Banyak kelebihan dari pertanian Hidroponik, tak hanya karena dapat menggunakan lahan yang terbatas, tetapi juga kualitas tanaman menjadi lebih baik dibanding dengan berkebun dengan menggunakan media tanam berupa tanah.

Bertanam dengan teknik Hidroponik dapat dijadikan sebagai hobi bahkan belajar untuk menciptakan sendiri lingkungan hijau di sekitar rumah. Namun bukan berarti Hidroponik hanya diperuntukkan sebatas sebagai hobi saja serta memanfaatkan lahan sempit di sekitar rumah, tetapi Hidroponik juga dapat di jadikan sebuah usaha untuk menghasilkan keuntungan yang besar disamping dapat membuka kesempatan bagi masyarakat untuk mengkonsumsi sendiri sayuran dan buahbuahan yang ditanaminya sendiri. Hidroponik merupakan sebuah solusi bagi masyarakat untuk mempertahankan lahan hijau dalam mengatasi kehidupan kota yang mulai tercemar dan kurangnya udara sejuk dalam suasana kehidupan di kota ditambah lagi merupakan salah satu solusi untuk ketahanan pangan. Namun usaha untuk mengembangkan pertanian Hidroponik terdapat kendala dan hambatan yang perlu dihadapi dan dibuat solusi. 
Persepsi masyarakat terhadap pertanian Hidroponik masih beragam, ada yang pro dan yang ada kontra. Saat ini masih banyak masyarakat yang bercocok tanam dengan menggunakan media tanah, karena bagi masyarakat bercocok tanam menggunakan Hidroponik memerlukan biaya yang sangat mahal dan harus mengikuti pelatihan untuk mendapatkan pengetahuan yang cukup agar berhasil dalam melakukan pertanian dengan teknik Hidroponik. Penduduk di Sulawesi Utara khususnya Kota Manado sudah mulai melakukan pertanian dengan teknik Hidroponik, walaupun belum banyak anggota masyarakat di daerah-daerah yang bercocok tanam dengan teknik Hidroponik. Salah satu tempat yang telah melakukan teknik pertanian dengan menggunakan teknik Hidroponik yaitu Kelurahan Teling Bawah di Kota Manado. Untuk itu perlu dilakukan penelitian untuk mengetahui bagaimana persepsi masyarakat terhadap Hidroponik di Kelurahan Teling Bawah, Kota Manado.

\section{Rumusan Masalah}

Berdasarkan latar belakang yang telah dikemukakan maka yang menjadi permasalahan dalam penelitian ini yaitu, bagaimana persepsi masyarakat terhadap Hidroponik di Kelurahan Teling Bawah Kota Manado?

\section{Tujuan Penelitian}

Penelitian ini bertujuan untuk mengetahui persepsi masyarakat terhadap Hidroponik di Kelurahan Teling Bawah Kota Manado?

\section{Manfaat Penelitian}

Manfaat dari makalah ini yaitu untuk menjadi bahan informasi dan bahan pertimbangan bagi pemerintah untuk dapat mengembangkan Hidroponik, bagi masyarakat penelitian ini kiranya dapat menjadi bahan informasi untuk bercocok tanam dengan menggunakan Hidroponik, dan menambah wawasan masyarakat tentang Hidroponik dan penelitian ini dapat menambah pengalaman bagi peneliti.

\section{METODOLOGI PENELITIAN}

\section{Lokasi dan Waktu Penelitian}

Penelitian ini akan dilakukan di Kelurahan Teling Bawah Kota Manado. Penelitian ini berlangsung lima bulan yaitu bulan November 2016 sampai bulan Maret 2017 yang dimulai dari persiapan sampai dengan laporan hasil penelitian.

\section{Metode Pengambilan Sampel}

Teknik pengambilan sampel adalah Purposive Sampling (Judgemental Sampling) yaitu teknik pengambilan sampel yang digunakan dalam situasi dimana seorang peneliti menggunakan penilaiannya dalam memilih responden dengan tujuan tertentu di dalam benaknya (Ibrahim, 2015). Jumlah responden yang di ambil yaitu 30 masyarakat di Kelurahan Teling Bawah Kota Manado.

\section{Metode Pengumpulan Data}

Penelitian ini menggunakan data primer dan data sekunder. Data primer diperoleh melalui wawancara langsung dengan responden berdasarkan daftar pertanyaan yang telah disiapkan (Kuesioner), sedangkan data sekunder diperoleh melalui dokumentasi dari instansi-instansi yang berkaitan dengan penelitian ini antara lain di Kantor Kelurahan Teling Bawah Kota Manado.

\section{Konsep Pengukuran Variabel}

Variabel-variabel yang diukur dalam penelitian ini, adalah:

\section{A. Identitas Responden}

1. Nama Responden

2. Umur, dinyatakan dengan satuan tahun

3. Jenis Kelamin (laki-laki/perempuan)

4. Tingkat pendidikan, diukur menurut tingkatan pendidikan yang sudah ditamatkan yaitu SD, SMP, SMA, perguruan tinggi

5. Pekerjaan yaitu pekerjaan yang dijalani oleh responden

\section{B. Persepsi Masyarakat Terhadap Hidroponik}

Persepsi masyarakat terhadap Hidroponik diukur dengan pertanyaanpertanyaan menyangkut 12 tema sebagai berikut: 


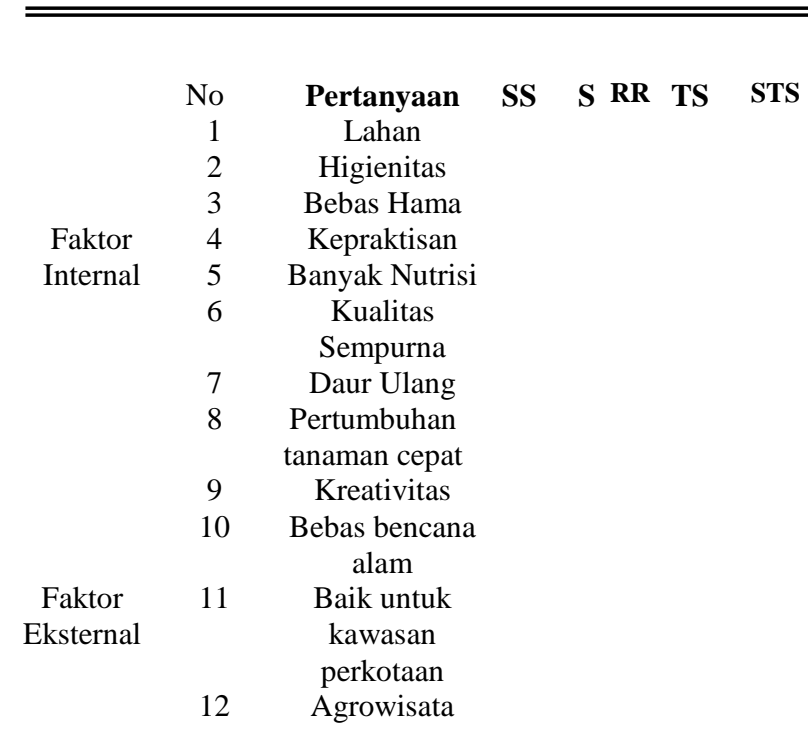

\section{Analisis Data}

Tahap analisis data bertujuan untuk mengetahui persepsi masyarakat terhadap Hidroponik di Kelurahan Teling Bawah Kota Manado. Teknik analisis data yang di gunakan dalam penelitian data ini adalah teknik analisis data deskriptif dengan menggunakan pengukuran pengskalaan Likert dengan menggunakan tabel data dan angka. Jumlah pertanyaan untuk mengukur persepsi masyarakat Kelurahan Teling Kota Manado yaitu 12 pertanyaan dengan total responden 30 orang. Setiap jawaban dihubungkan dengan bentuk pertanyaan dan dukungan yang diungkapkan dengan kata-kata dan dikategorikan sebagai berikut

$$
\begin{aligned}
& \text { a.SS: Sangat setuju skor: } 5 \\
& \text { b.ST : Setuju skor: } 4 \\
& \text { c.RR: Ragu-Ragu skor: } 3 \\
& \text { d.TS: Tidak setuju skor: } 2 \\
& \text { e.STS:Sangat tidak setuju skor: } 1 \\
& \text { Dengan cara perhitungan skor: } \\
& \text { Jumlah Skor Tiap Kriterium = Capaian Skor } \\
& \mathrm{X} \text { Jumlah Responden } \\
& \mathrm{S}_{5}=5 \times 30=150 \\
& \mathrm{~S}_{4}=4 \times 30=120 \\
& \mathrm{~S}_{3}=3 \times 30=90 \\
& \mathrm{~S}_{2}=2 \times 30=60 \\
& \mathrm{~S}_{1}=1 \times 30=3
\end{aligned}
$$

Jumlah Skor tertinggi $=150$, dan jumlah Skor terendah $=30$. Dengan interprestasi nilai

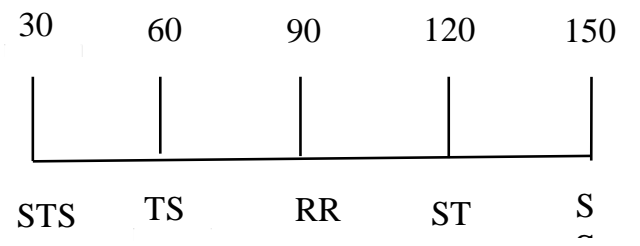

Cara perhitungan skor keseluruhan untuk mengetahui persepsi masyarakat terhadap Hidroponik yaitu:

Jumlah Skor Seluruh Kriterium $=$ Capaian Jumlah Skor X Jumlah responden X Jumlah pertanyaan

$$
\begin{aligned}
& \mathrm{S} 5=5 \times 30 \times 12=1800 \\
& \mathrm{~S} 4=4 \times 30 \times 12=1440 \\
& \mathrm{~S} 3=3 \times 30 \times 12=1080 \\
& \mathrm{~S} 2=2 \times 30 \times 12=720 \\
& \mathrm{~S} 1=1 \times 30 \times 12=360
\end{aligned}
$$

Jumlah Skor ideal untuk keseluruhan pertanyaan tertinggi $=1800$

Jumlah Skor terendah $=360$

Dengan interpretasi nilai

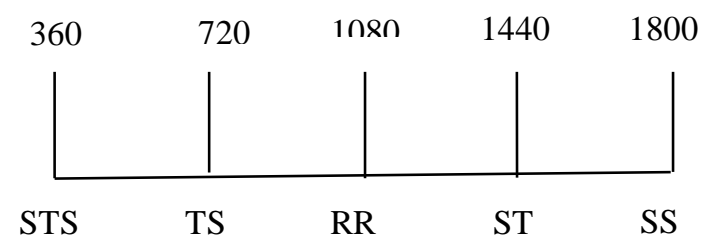

Analisis data yang digunakan merupakan analisis deskriptif yang dianalisis dengan menggunakan Skala Likert (Likert Scale) dimana menurut Riduwan (2008) sebagai berikut:

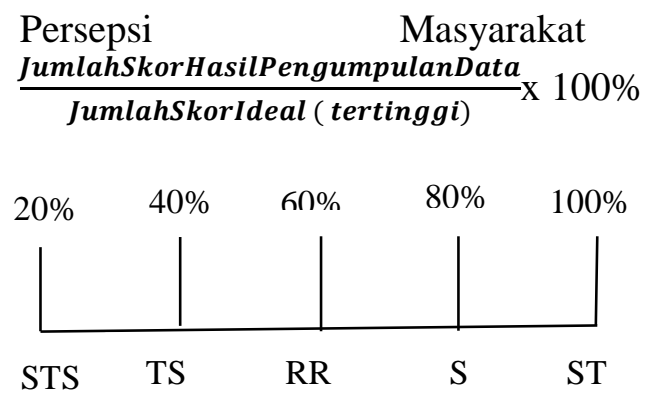

Keterangan interpretasi skor:

$\begin{array}{ll}\text { Angka } 0 \%-20 \% & =\text { Sangat tidak setuju } \\ \text { Angka } 21 \%-40 \% & =\text { Tidak setuju } \\ \text { Angka } 41 \%-60 \% & =\text { Ragu-ragu } \\ \text { Angka } 61 \%-80 \% & =\text { Setuju } \\ \text { Angka } 81 \%-100 \% & =\text { Sangat setuju }\end{array}$

\section{HASIL DAN PEMBAHASAN}

\section{Keadaan Kelurahan Teling Bawah Kota Manado}

Gambaran umum tentang Kelurahan Teling Bawah meliputi sejarah, letak geografi dan batas-batas wilayah, kondisi penduduk 
menurut jenis kelamin, tingkat pendidikan, mata pencaharian, dan agama.

\section{Sejarah Desa/Kelurahan Teling Bawah Kota Manado}

Sebelum menjadi lokasi pemukiman, wilayah Teling adalah ondernemeng kelapa. Tanahnya yang subur selain sebagai perkebunan kelapa, juga merupakan habitat pohon bulu (bahasa Manado), yang artinya bambu. Jumlah pohon bambu yang melimpah mengilhami penduduk yang mendiaminya dan memberi nama Teling. Teling diambil dari kata teling (bahasa Tombulu) dan telring (bahasa Bantik). Teling dan Telring memiliki arti yang sama yaitu bambu atau bulu. Ada dua Kelurahan yang bernama Teling di Kota Manado, yaitu Teling Atas, Kecamatan Wanea dan Teling Bawah, Kecamatan Wenang.

\section{Letak Geografi dan Batas-batas Wilayah Kelurahan Teling Bawah Kota Manado}

Kelurahan Teling Bawah memiliki jarak dengan ibu kota Kecamatan Wenang 0,5 kilometer, jarak dengan ibukota Kecamatan Wanea 0,7 kilometer, dan jarak dengan ibukota provinsi (Kota Manado) 0,8 kilometer. Kelurahan Teling Bawah memiliki luas sekitar 30 hektar yang terdiri atas 7 lingkungan.

Batas wilayah administratif Kelurahan Teling Bawah sebagai berikut :

- Sebelah Utara berbatasan dengan Tikala Kumaraka-Kecamatan Wenang

- Sebelah Selatan berbatasan dengan Teling Atas-Kecamatan Wanea

- Sebelah Timur berbatasan dengan BanjerKecamatan Tikala

- Sebelah Barat berbatasan dengan Bumi Beringin-Kecamatan Wenang

\section{Penduduk menurut Jenis Kelamin Di Kelurahan Teling Bawah Kota Manado \\ Pembedaan masyarakat berdasarkan} jenis kelamin menjelaskan tentang keadaan jumlah jiwa laki-laki dan perempuan yang ada di Kelurahan Teling Bawah. Penduduk Kelurahan Teling Bawah menurut jenis kelamin dapat dilihat pada Tabel 1. Tabel 1 menunjukkan bahwa penduduk perempuan lebih banyak jumlahnya dari penduduk laki-laki yang mengindikasikan bahwa tidak banyak tersedia lapangan kerja di kelurahan ini.

Tabel 1. Jumlah Penduduk menurut Jenis Kelamin di Kelurahan Teling Bawah Kota Manado

\begin{tabular}{cccc}
\hline \multirow{2}{*}{ No } & Jenis & Jumlah & Persentase \\
& kelamin & jiwa & $(\%)$ \\
\hline 1 & Laki-laki & 1.977 & 49.9 \\
2 & Perempuan & 1.982 & 50.1 \\
\hline & Jumlah & 3.959 & 100 \\
\hline
\end{tabular}

Sumber : Kantor Kelurahan Teling Bawah, 2016

\section{Penduduk menurut Tingkat Pendidikan Di} Kelurahan Teling Bawah Kota Manado

Latar belakang pendidikan responden akan mempengaruhi dalam kehidupan maupun pekerjaan. Tabel 2 menggambarkan tingkat pendidikan responden dari TK sampai perguruan tinggi. Tabel 2 menunjukkan bahwa penduduk yang tidak tamat SD, SMP dan SMA (usia 15 s/d 56 tahun) sebesar lebih dari $10 \%$ $(12,37 \%)$. Penduduk yang sedang bersekolah pada tingkat TK sampai SMA (usia 3 tahun sampai 18 tahun) sebanyak $17,80 \%$. Terdapat kecenderungan bahwa semakin tinggi tingkat pendidikan semakin sedikit jumlah penduduk yang dapat mencapainya.

\begin{tabular}{|c|c|c|c|}
\hline \multicolumn{4}{|c|}{$\begin{array}{l}\text { Tabel 2. Jumlah Penduduk Menurut Tingkat } \\
\text { Pendidikan di Kelurahan Teling } \\
\text { Bawah Kota Manado }\end{array}$} \\
\hline No & Pendidikan & Jumlah & $\begin{array}{c}\text { Persentase } \\
(\%)\end{array}$ \\
\hline 1 & Belum masuk TK & 7 & 0,17 \\
\hline 2 & $\begin{array}{l}\text { Sedang sekolah } \\
\text { (TK-SMA) }\end{array}$ & 705 & 17,80 \\
\hline 3 & $\begin{array}{l}\text { Tidak pernah } \\
\text { sekolah }\end{array}$ & 17 & 0,42 \\
\hline 4 & $\begin{array}{l}\text { Tamat SD dan } \\
\text { Tidak tamat SD }\end{array}$ & 434 & 10,96 \\
\hline 5 & Tamat SMP & 960 & 24,24 \\
\hline 6 & Tamat SMA & 1417 & 35,79 \\
\hline 7 & Diploma (1-3) & 141 & 3,56 \\
\hline 8 & Sarjana (S1 \& S2) & 278 & 7,02 \\
\hline & Jumlah & 3959 & 100 \\
\hline
\end{tabular}

Sumber: Kantor Kelurahan Teling Bawah, 2016 
Penduduk menurut Mata Pencaharian di Kelurahan Teling Bawah Kota Manado

Penduduk menurut mata pencaharian menjelaskan mengenai jenis-jenis mata pencaharian yang tersedia di Kelurahan Teling Bawah. Jenis-jenis mata pencaharian ini yang merupakan sumber pendapatan penduduk. Penduduk Kelurahan Teling Bawah menurut mata pencaharian dapat dilihat pada Tabel 3. Tabel 3 menunjukkan bahwa penduduk yang bekerja pada pemerintah sebagai PNS, TNI, Polri sebesar 9,85\% sedangkan yang bekerja sebagai karyawan swasta $11,36 \%$. Terdapat pula penduduk yang bekerja sebagai sopir, ojek dan guru sebesar $26,4 \%$.

\section{Tabel 3. Penduduk Menurut Mata Pencaharian Di Kelurahan Teling Bawah Kota Manado}

\begin{tabular}{|c|c|c|c|}
\hline No & Mata Pencaharian & $\begin{array}{c}\text { Jumla } \\
h\end{array}$ & $\begin{array}{c}\text { Persentase } \\
(\%)\end{array}$ \\
\hline 1 & $\begin{array}{c}\text { Pegawai Negeri } \\
\text { Sipil }\end{array}$ & 245 & 6,1 \\
\hline 2 & Pedagang keliling & 13 & 0,3 \\
\hline 3 & Montir & 9 & 0,2 \\
\hline 4 & Dokter Swasta & 3 & 0,07 \\
\hline 5 & Perawat Swasta & 14 & 0,35 \\
\hline 6 & $\begin{array}{c}\text { Pembantu Rumah } \\
\text { Tangga }\end{array}$ & 22 & 0,55 \\
\hline 7 & TNI & 133 & 3,35 \\
\hline 8 & POLRI & 16 & 0,40 \\
\hline 9 & Pensiunan & 76 & 1,91 \\
\hline 10 & Pengacara & 1 & 0,02 \\
\hline 11 & Dukun & 2 & 0,05 \\
\hline 12 & Dosen & 7 & 0,42 \\
\hline 13 & Arsitektur & 1 & 0,02 \\
\hline 14 & Karyawan Swasta & 450 & 11,36 \\
\hline 15 & $\begin{array}{l}\text { Karyawan } \\
\text { Pemerintah }\end{array}$ & 54 & 1,36 \\
\hline 16 & Pelajar & 788 & 19,90 \\
\hline 17 & Ibu Rumah Tangga & 742 & 18,74 \\
\hline 18 & Belum Bekerja & 352 & 8,89 \\
\hline 19 & $\begin{array}{c}\text { Lain-lain } \\
\text { (Ojek,Guru,Sopir) }\end{array}$ & 1031 & 26,04 \\
\hline & Jumlah & 3959 & 100 \\
\hline
\end{tabular}

Penduduk berdasarkan Agama Di Kelurahan Teling Bawah Kota Manado

Penduduk menurut agama menjelaskan tentang kondisi keagamaan yang ada di Kelurahan Teling Bawah. Penduduk Kelurahan Teling Bawah menurut agama dapat dilihat pada Tabel 4. Tabel 4 menunjukkan kebanyakan penduduk $(78,5 \%)$ memeluk agama Kristen sedangkan yang tersedikit $0,22 \%$ memeluk agama Budha.

Tabel 4. Penduduk menurut Agama Di Kelurahan Teling Bawah Kota Manado

\begin{tabular}{cccc}
\hline No & Agama & Jumlah & Persentase $(\%)$ \\
\hline 1 & Kristen & 3106 & 78,5 \\
2 & Katolik & 225 & 5,7 \\
3 & Islam & 599 & 15,13 \\
4 & Hindu & 20 & 0,50 \\
5 & Budha & 9 & 0,22 \\
\hline & Jumlah & 3959 & 100 \\
\hline
\end{tabular}

Sumber: Kantor Kelurahan Teling Bawah, 2016

\section{Umur Responden \\ Karakteristik Responden \\ Klasifikasi umur responden di} Kelurahan Teling Bawah dapat dilihat pada Tabel 5. Pada Tabel 5 dapat dilihat bahwa persentase tingkat umur yang tertinggi dari responden yang tinggal di Kelurahan Teling Bawah adalah klasifikasi responden yang berumur 19-24 Tahun dengan jumlah 8 orang dengan persentase $26,66 \%$ dan yang terendah responden yang berumur 46-50 tahun berjumlah 1 orang dengan presentase $3,34 \%$.

Tabel 5. Klasifikasi Responden Menurut Kelompok Umur

\begin{tabular}{cccc}
\hline No & Umur & $\begin{array}{c}\text { Jumlah } \\
\text { Responden }\end{array}$ & Persentase (\%) \\
\hline 1 & $19-24$ & 8 & 26,66 \\
2 & $25-30$ & 6 & 20,00 \\
3 & $31-35$ & 6 & 20,00 \\
4 & $36-40$ & 6 & 20,00 \\
5 & $41-45$ & 3 & 10,00 \\
6 & $46-50$ & 1 & 3,34 \\
\hline & Jumlah & 30 & 100 \\
\hline
\end{tabular}

Sumber : Data Hasil Olahan 2017 


\section{Jenis Kelamin Responden}

Klasifikasi responden berdasarkan jenis kelamin dapat dilihat pada Tabel 6. Pada Tabel 6 memperlihatkan bahwa jumlah responden berdasarkan jenis kelamin sebagian besar adalah laki-laki berjumlah 24 orang dengan persentase $80,00 \%$. Sedangkan perempuan berjumlah 6 orang dengan persentase $20,00 \%$

\section{Tabel 6. Klasifikasi Responden Berdasarkan Jenis Kelamin}

\begin{tabular}{cccc}
\hline No & $\begin{array}{c}\text { Jenis } \\
\text { Kelamin }\end{array}$ & $\begin{array}{c}\text { Jumlah } \\
\text { Responden }\end{array}$ & $\begin{array}{c}\text { Persentase } \\
(\%)\end{array}$ \\
\hline 1 & Laki-Laki & 24 & 80,00 \\
2 & Perempuan & 6 & 20,00 \\
\hline & Jumlah & 30 & 100 \\
\hline
\end{tabular}

Sumber : Data Hasil Olahan ,2017

\section{Pendidikan Responden}

Klasifikasi responden berdasarkan pendidikan dapat dilihat pada Tabel 7. Pada Tabel 7 dapat dilihat bahwa sebagian besar responden memiliki tingkat pendidikan SMA/SMK dengan jumlah 23 orang dengan persentase $76.67 \%$ dan tingat pendidikan S1 dengan jumlah 6 orang dengan persentase $20,00 \%$. Dan yang terendah tingkat pendidikan responden D3 dengan jumlah 1 orang dengan persentase $3,34 \%$.

\section{Tabel 7. Klasifikasi Responden Berdasarkan} Tingkat Pendidikan

\begin{tabular}{|c|c|c|c|}
\hline No & $\begin{array}{l}\text { Tingkat } \\
\text { Pendidikan }\end{array}$ & $\begin{array}{c}\text { Jumlah } \\
\text { Responden }\end{array}$ & $\begin{array}{c}\text { Persentase } \\
(\%)\end{array}$ \\
\hline 1 & SMA/SMK & 23 & 76,66 \\
\hline 2 & S1 & 6 & 20,00 \\
\hline 3 & D3 & 1 & 3,34 \\
\hline & Jumlah & 30 & $100 \%$ \\
\hline
\end{tabular}

Sumber : Data Hasil Olahan , 2017

\section{Pekerjaan Responden}

Untuk mengetahui klasifikasi responden berdasarkan jenis pekerjaan dapat dilihat pada Tabel 8 .
Tabel 8. Klasifikasi Responden Berdasarkan Pekerjaan

\begin{tabular}{|c|c|c|c|}
\hline No & $\begin{array}{c}\text { Jenis } \\
\text { Pekerjaan }\end{array}$ & $\begin{array}{c}\text { Jumlah } \\
\text { Responden }\end{array}$ & $\begin{array}{c}\text { Persentase } \\
(\%)\end{array}$ \\
\hline 1 & TNI-AD & 21 & 70,00 \\
\hline 2 & $\begin{array}{c}\text { Mahasiswa / } \\
\text { Pelajar }\end{array}$ & 2 & 6,66 \\
\hline 3 & Pedagang & 2 & 6,66 \\
\hline 4 & Lurah & 1 & 3,34 \\
\hline 5 & $\begin{array}{c}\text { Kepala } \\
\text { Lingkungan }\end{array}$ & 1 & 3,34 \\
\hline 6 & $\begin{array}{l}\text { Pegawai } \\
\text { Negeri Sipil } \\
\text { Ibu Rumah }\end{array}$ & 1 & 3,34 \\
\hline 7 & $\begin{array}{c}\text { Tangga } \\
\text { (IRT) }\end{array}$ & 2 & 6,66 \\
\hline & Jumlah & 30 & 100 \\
\hline
\end{tabular}

Sumber : Data Hasil Olahan , 2017

Tabel 8 menunjukkan bahwa jumlah terbanyak responden merupakan anggota TNI$\mathrm{AD}$ yaitu sebanyak 21 orang dengan persentase $70,00 \%$, Mahasiswa/Pelajar sebanyak 2 orang dengan persentase $6,66 \%$, Pedagang sebanyak 2 orang dengan persentase $6,66 \%$, Lurah berjumlah 1 orang dengan persentase 3,34\%, Kepala Lingkungan berjumlah 1 orang dengan persentase 3,34\%.Pegawai Negeri Sipil berjumlah 1 orang dengan persentase $3,34 \%$,dan Ibu Rumah Tangga (IRT) berjumlah 2 orang dengan persentase $6,66 \%$.

\section{Persepsi Anggota Masyarakat}

Persepsi masyarakat terhadap Hidroponik dalam penelitian ini adalah menyangkut penilaian positif atau negatif yang diberikan oleh anggota masyarakat terhadap Hidroponik yang ada di Kelurahan Teling Bawah, Kota Manado. Persepsi masyarakat terhadap Hidroponik di Kelurahan Teling Bawah Kota Manado dibedakan dalam dua faktor yaitu menurut Faktor Internal dan Faktor Eksternal. Faktor Internal yaitu Persepsi masyarakat terhadap: Lahan, Higienitas, Hama, Kepraktisan, Nutrisi, Kualitas Tanaman, Daur Ulang, Pertumbuhan Tanaman Cepat, Kreativitas, Bencana Alam. Sedangkan untuk Faktor Eksternal yaitu Persepsi masyarakat terhadap Hidroponik baik untuk kawasan perkotaan maupun untuk Agrowisata. 


\section{Persepsi Masyarakat menurut Faktor Internal}

\section{Lahan}

Persepsi masyarakat tentang Hidroponik menyangkut Lahan/Ruang adalah apakah budidaya pertanian Hidroponik dapat menghemat lahan atau ruang atau tidak. Tabel 9 menunjukan bahwa sebagian besar responden, yaitu $18(60,00 \%)$ masyarakat di Kelurahan Teling Bawah Kota Manado sangat setuju, serta terdapat $11(40,00 \%)$ yang setuju bahwa Hidroponik merupakan teknik pertanian yang hemat lahan/ruang. Dalam indikator ini, total skor persepsi masyarakat sebesar 134/150 x $100 \%=89,33 \%$, sehingga interpretasi nilainya tergolong sangat setuju. Sesuai dengan hasil wawancara pada anggota masyarakat yang berpendapat sangat setuju terhadap Hidroponik hemat Lahan/ruang adalah karena Hidroponik tidak menggunakan tanah sebagai media tanam, dapat ditanam di mana saja, bisa dibuat dalam sistim yang bertingkat serta lahannya lebih hemat dibandingkan pertanian konvensional.

Tabel 9. Persepsi Masyarakat Terhadap Hidroponik Hemat Lahan/Ruang

\begin{tabular}{ccccc}
\hline $\begin{array}{c}\text { Alternatif } \\
\text { Jawaban }\end{array}$ & Skor & $\begin{array}{c}\text { Jumlah } \\
\text { Responden }\end{array}$ & $\begin{array}{c}\text { Persentase } \\
(\%)\end{array}$ & $\begin{array}{c}\text { Total } \\
\text { Skor }\end{array}$ \\
\hline $\begin{array}{c}\text { Sangat } \\
\text { Setuju }\end{array}$ & 5 & 18 & 60,00 & 90 \\
Setuju & 4 & 11 & 40,00 & 44 \\
Ragu-Ragu & 3 & - & - & - \\
Tidak & 2 & - & - & - \\
Setuju & & & - & - \\
Sangat & & - & & \\
Tidak & 1 & & 100 & 134 \\
Setuju & & & & \\
\hline Jumlah & & 30 & & \\
\hline Sumb: Diah
\end{tabular}

Sumber : Diolah dari data primer, 2017

\section{Higienitas}

Tabel 10 menunjukkan bahwa sebagian besar responden, yaitu 19 (63,33\%) masyarakat di Kelurahan Teling Bawah Kota Manado setuju, serta terdapat $11 \quad(36,67 \%)$ yang mengatakan sangat setuju bahwa Hasil tanaman Hidroponik sangat Higienis. Dalam indikator ini, total skor persepsi masyarakat sebesar $131 / 150 \times 100 \%=87,33 \%$, sehingga interpretasi nilainya tergolong sangat setuju.
Alasan dari anggota masyarakat yang menyatakan sangat setuju dan setuju terhadap Hasil Tanaman Hidroponik higienis, berdasarkan hasil wawancara, karena Hidroponik tidak menggunakan bahan-bahan yang mengandung zat-zat kimia dan tidak bersentuhan langsung dengan tanah sehingga tanaman bisa terkontrol dengan baik dan sangat higienis dan sangat berguna untuk kesehatan.

Tabel 10. Persepsi Masyarakat Terhadap Hasil Tanaman Hidroponik Higienis

\begin{tabular}{ccccc}
\hline $\begin{array}{c}\text { Alternatif } \\
\text { Jawaban }\end{array}$ & Skor & $\begin{array}{c}\text { Jumlah } \\
\text { Responden }\end{array}$ & $\begin{array}{c}\text { Persentase } \\
(\%)\end{array}$ & $\begin{array}{c}\text { Total } \\
\text { Skor }\end{array}$ \\
\hline $\begin{array}{c}\text { Sangat } \\
\text { Setuju }\end{array}$ & 5 & 11 & 36,67 & 55 \\
Setuju & 4 & 19 & 63,33 & 76 \\
Ragu-Ragu & 3 & - & - & - \\
Tidak Setuju & 2 & - & - & - \\
$\begin{array}{c}\text { Sangat } \\
\text { Tidak Setuju }\end{array}$ & 1 & - & - & - \\
\hline Jumlah & & 30 & 100 & 131 \\
\hline
\end{tabular}

Sumber : Diolah dari data primer, 2017

\section{Bebas Hama}

Tabel 11 menunjukkan bahwa sebagian besar responden, yaitu 12 (40,00\%) masyarakat di Kelurahan Teling Bawah Kota Manado setuju, serta terdapat $5(16,67 \%)$ setuju , terdapat juga $9(30,00 \%)$ yang ragu-ragu dan 4 $(13,33 \%)$ yang tidak setuju.. Dalam indikator ini, total skor persepsi masyarakat sebesar 108/150 x $100 \%=72,00 \%$, sehingga interpretasi nilainya tergolong setuju. Alasan dari responden yang menyatakan sangat setuju dan setuju terhadap pernyataan Hidroponik bebas hama dan parasit adalah dikarenakan Hidroponik mendapat perawatan yang cukup baik nutrisi dan kelembaban suhu, ada juga yang mengatakan sampai saat ini ketika ia menanam tanaman dengan menggunakan teknik Hidroponik tidak pernah menemukan tanaman diserang hama. Tapi ada juga responden yang mengatakan ragu-ragu dan tidak setuju bahwa Hidroponik bebas hama dan parasit, hal itu dikarenakan sesuai dengan pengalaman mereka menanam dengan teknik Hidroponik, kadang tanaman tersebut diserang hama yang membuat daunnya rusak. 
Tabel 11. Persepsi Masyarakat Terhadap Hidroponik Bebas Hama dan Parasit

\begin{tabular}{ccccc}
\hline $\begin{array}{c}\text { Alternatif } \\
\text { Jawaban }\end{array}$ & Skor & $\begin{array}{c}\text { Jumlah } \\
\text { Responden }\end{array}$ & $\begin{array}{c}\text { Persentase } \\
(\%)\end{array}$ & $\begin{array}{c}\text { Total } \\
\text { Skor }\end{array}$ \\
\hline Sangat Setuju & 5 & 5 & 16,67 & 25 \\
Setuju & 4 & 12 & 40,00 & 48 \\
Ragu-Ragu & 3 & 9 & 30,00 & 27 \\
Tidak Setuju & 2 & 4 & 13,33 & 8 \\
Sangat Tidak & 1 & - & - & - \\
Setuju & & & 100 & 108 \\
\hline Jumlah & & 30 & &
\end{tabular}

Sumber : Diolah dari data primer, 2017

\section{Kepraktisan Tanaman Hidroponik}

Tabel 12 menunjukkan bahwa sebagian besar responden, yaitu $17(56,67 \%)$ masyarakat di Kelurahan Teling Bawah Kota Manado setuju, serta terdapat $10(33,33 \%)$ yang sangat setuju, terdapat juga $2(6,67 \%)$ yang ragu-ragu dan $1(3,33 \%)$ yang tidak setuju bahwa perawatan Hidroponik praktis. Dalam indikator ini, total skor persepsi masyarakat sebesar $126 / 150 \times 100 \%=84,00 \%$, sehingga interpretasi nilainya tergolong sangat setuju. Sesuai dengan hasil wawancara pada responden yang menjawab sangat setuju dan setuju terhadap perawatan Hidroponik yang praktis, mereka beralasan bahwa merawat Hidroponik tidak memerlukan waktu yang lama, dan pemberian pupuk lebih praktis dibandingkan dengan perawatan tanaman pada pertanian konvensional. Alasan yang dikemukakan oleh responden yang memberikan jawaban ragu-ragu dan tidak adalah karena nutrisi Hidroponik membuat perawatan Hidroponik tidak terlalu praktis.

Tabel 12. Persepsi Masyarakat Terhadap Perawatan Hidroponik yang Praktis

\begin{tabular}{lcccc}
\hline $\begin{array}{c}\text { Alternatif } \\
\text { Jawaban }\end{array}$ & Skor & $\begin{array}{c}\text { Jumlah } \\
\text { Responden }\end{array}$ & $\begin{array}{c}\text { Persentase } \\
(\%)\end{array}$ & $\begin{array}{c}\text { Total } \\
\text { Skor }\end{array}$ \\
\hline Sangat & 5 & 10 & 33,33 & 50 \\
Setuju & & & & \\
Setuju & 4 & 17 & 56,67 & 68 \\
Ragu-Ragu & 3 & 2 & 6,67 & 6 \\
Tidak Setuju & 2 & 1 & 3,33 & 2 \\
Sangat & 1 & - & - & \\
Tidak Setuju & & & & \\
\hline \multicolumn{1}{c}{ Jumlah } & 30 & 100 & 126 \\
\hline
\end{tabular}

Sumber : Diolah dari data primer, 2017

\section{Memberikan lebih banyak Nutrisi}

Tabel 13 menunjukkan bahwa sebagian besar responden, yaitu $16(53,33 \%)$ masyarakat di Kelurahan Teling Bawah Kota Manado setuju, serta terdapat $5 \quad(16,67 \%)$ sangat setuju, dan juga terdapat $6(20,00 \%)$ raguragu dan $3(10,00 \%)$ tidak setuju bahwa Hidroponik memberikan lebih banyak nutrisi kepada tanaman. Dalam indikator ini, total skor persepsi masyarakat sebesar $113 / 150 \times 100 \%=$ $75,33 \%$, sehingga interpretasi nilainya tergolong setuju. Alasan responden yang menyatakan sangat setuju dan setuju bahwa Hidroponik memberikan lebih banyak nutrisi kepada tanaman dikarenakan menurut mereka tanaman Hidroponik tumbuh dengan cara kerja air yang telah terukur dan mendapat pasokan nutrisi yang telah diukur pula dan nutrisinya terkontrol dengan baik serta pertanian Hidroponik menggunakan air. Sedangkan alasan yang melatarbelakangi sebagian masyarakat berpendapat ragu-ragu dan tidak setuju adalah tergantung dari seberapa banyak nutrisi yang diberikan kepada tanaman, karena nutrisi hidroponik sangat sulit diperoleh, beberapa responden mengatakan mereka perlu berhemat terhadap pemberian nutrisi kepada tanaman Hidroponik karena sulitnya mendapat nutrisi Hidroponik di daerah tempat tinggal sendiri (Kota Manado) karena mereka harus membeli dari luar daerah.

Tabel 13. Persepsi Masyarakat bahwa Hidroponik memberikan lebih banyak Nutrisi kepada tanaman

\begin{tabular}{ccccc}
\hline $\begin{array}{c}\text { Alternatif } \\
\text { Jawaban }\end{array}$ & Skor & $\begin{array}{c}\text { Jumlah } \\
\text { Responden }\end{array}$ & $\begin{array}{c}\text { Persentase } \\
(\%)\end{array}$ & $\begin{array}{c}\text { Total } \\
\text { Skor }\end{array}$ \\
\hline $\begin{array}{c}\text { Sangat } \\
\text { Setuju }\end{array}$ & 5 & 5 & 16,67 & 25 \\
$\begin{array}{c}\text { Setuju } \\
\text { Ragu-Ragu }\end{array}$ & 4 & 16 & 53,33 & 64 \\
Tidak & 2 & 6 & 20,00 & 18 \\
Setuju & 3 & 10,00 & 6 \\
$\begin{array}{c}\text { Sangat } \\
\text { Tidak }\end{array}$ & 1 & - & - & - \\
Setuju & & & 100 & 113 \\
\hline Jumlah & & 30 &
\end{tabular}

Sumber : Diolah dari data primer, 2017 


\section{Kualitas Sempurna}

Tabel 14 menunjukkan bahwa sebagian besar responden, yaitu $13(43,34 \%)$ masyarakat di Kelurahan Teling Bawah Kota Manado setuju, serta terdapat $12(40,00 \%)$ sangat setuju, dan juga terdapat $4(13,33 \%)$ raguragu dan $1(3,33 \%)$ tidak setuju bahwa kualitas tanaman Hidroponik sempurna. Dalam indikator ini, total skor persepsi masyarakat sebesar $126 / 150 \times 100 \%=84,00 \%$, sehingga interpretasi nilainya tergolong sangat setuju. Berdasarkan hasil wawancara, hal yang melatarbelakangi persepsi masyarakat sangat setuju dan setuju bahwa kualitas tanaman Hidroponik sempurna adalah dikarenakan tanaman Hidroponik sangat terkontrol dengan baik dalam proses pertumbuhannya dan berdasarkan pengalaman mereka sebagai pelaku Hidroponik ketika menanam sayur dengan teknik Hidroponik hasilnya tidak pahit dan sayurannya sangat segar contohnya sayur selada. Sedangkan menurut responden yang mengatakan ragu-ragu dan tidak setuju, alasannya karena kadang daun dari tanaman Hidroponik diserang hama jika tidak terkontrol dengan baik, jika air tidak diganti maka daunnya akan cepat rusak.

Tabel 14. Persepsi Masyarakat Terhadap Kualitas Tanaman Hidroponik Yang Sempurna

\begin{tabular}{ccccc}
\hline $\begin{array}{c}\text { Alternatif } \\
\text { Jawaban }\end{array}$ & Skor & $\begin{array}{c}\text { Jumlah } \\
\text { Responden }\end{array}$ & $\begin{array}{c}\text { Persentase } \\
(\%)\end{array}$ & $\begin{array}{c}\text { Total } \\
\text { Skor }\end{array}$ \\
\hline $\begin{array}{c}\text { Sangat } \\
\text { Setuju }\end{array}$ & 5 & 12 & 40,00 & 60 \\
Setuju & 4 & 13 & 43,34 & 52 \\
Ragu-Ragu & 3 & 4 & 13,33 & 12 \\
Tidak Setuju & 2 & 1 & 3,33 & 2 \\
Sangat Tidak & 1 & - & - & \\
Setuju & & 30 & 100 & 126 \\
\hline Jumlah & \multicolumn{3}{c}{} \\
\hline Sumber : Diolah dari data primer,2017
\end{tabular}

\section{Daur Ulang}

Tabel 15 menunjukkan bahwa sebagian besar responden, yaitu $16(53,34 \%)$ masyarakat di Kelurahan Teling Bawah Kota Manado sangat setuju, serta terdapat $13(43,33 \%)$ setuju, dan juga terdapat $1 \quad(13,33 \%)$ ragu-ragu bahwa Hidroponik dapat memanfaatkan barangbarang bekas di rumah (Daur ulang). Dalam indikator ini, total skor persepsi masyarakat sebesar 135/150x $100 \%=90,00 \%$, sehingga interpretasi nilainya tergolong sangat setuju.

Tabel 15. Persepsi Masyarakat Terhadap Hidroponik Dapat Memanfaatkan Barang-Barang Bekas Di Rumah

\begin{tabular}{ccccc}
\hline $\begin{array}{c}\text { Alternatif } \\
\text { Jawaban }\end{array}$ & Skor & $\begin{array}{c}\text { Jumlah } \\
\text { Responden }\end{array}$ & $\begin{array}{c}\text { Persentase } \\
(\%)\end{array}$ & $\begin{array}{c}\text { Total } \\
\text { Skor }\end{array}$ \\
\hline $\begin{array}{c}\text { Sangat } \\
\text { Setuju }\end{array}$ & 5 & 16 & 53,34 & 80 \\
Setuju & 4 & 13 & 43,33 & 52 \\
Ragu-Ragu & 3 & 1 & 13,33 & 3 \\
Tidak Setuju & 2 & - & - & - \\
Sangat Tidak & 1 & - & - & - \\
Setuju & 1 & 30 & 100 & 135 \\
\hline Jumlah & & & &
\end{tabular}

Sumber : Diolah dari data primer, 2017

Alasan yang dikemukakan oleh responden yang menyatakan sangat setuju dan setuju bahwa Hidroponik dapat memanfaatkan barang-barang bekas di rumah (yang merupakan tindakan daur ulang) adalah Hidroponik dapat memanfaatkan barang-barang bekas seperti botol Aqua, gelas Aqua dan Jerigen, sedangkan menurut responden yang mengatakan ragu-ragu, alasannya adalah tergantung dengan tipe Hidroponik, karena tipe Hidroponik ada bermacam-macam, ada yang bisa memanfaatkan barang-barang bekas di rumah, tapi ada juga yang membutuhkan biaya yang sangat mahal seperti tipe Hidroponik yang menggunakan paralon.

\section{Pertumbuhan Tanaman Cepat}

Tabel 16 menunjukkan bahwa sebagian besar responden, yaitu $17(56,67 \%)$ masyarakat di Kelurahan Teling Bawah Kota Manado setuju,serta terdapat $5(16,67 \%)$ sangat setuju, dan juga terdapat $6(20,00 \%)$ ragu-ragu dan 2 $(6,66 \%)$ tidak setuju bahwa Hidroponik dapat mempercepat pertumbuhan tanaman. Dalam indikator ini, total skor persepsi masyarakat sebesar $115 / 150 \times 100 \%=76,67 \%$, sehingga interpretasi nilainya tergolong setuju. 
Tabel 16. Persepsi Masyarakat Terhadap Hidroponik Dapat Mempercepat Pertumbuhan Tanaman

\begin{tabular}{ccccc}
\hline $\begin{array}{c}\text { Alternatif } \\
\text { Jawaban }\end{array}$ & Skor & $\begin{array}{c}\text { Jumlah } \\
\text { Responden }\end{array}$ & $\begin{array}{c}\text { Persentase } \\
(\%)\end{array}$ & $\begin{array}{c}\text { Total } \\
\text { Skor }\end{array}$ \\
\hline Sangat & 5 & 5 & 16,67 & 25 \\
Setuju & & 17 & 56,67 & 68 \\
Setuju & 4 & 6 & 20,00 & 18 \\
Ragu-Ragu & 3 & 2 & 6,66 & 4 \\
Tidak Setuju & 2 & - & - & - \\
Sangat & 1 & & 100 & 115 \\
Tidak Setuju & & & &
\end{tabular}

Sumber : Diolah dari data primer, 2017

Sesuai dengan hasil wawancara, alasan yang melatarbelakangi persepsi masyarakat sangat setuju dan setuju bahwa Hidroponik dapat mempercepat pertumbuhan tanaman adalah karena tanaman Hidroponik lebih banyak mendapat pasokan air dibanding tanaman yang menggunakan teknik pertanian kovensional dan jika perawatannya sangat terkontrol dengan baik maka dapat mempercepat pertumbuhan tanaman. Sedangkan menurut responden yang ragu-ragu dan tidak setuju, alasannya adalah tergantung jenis tanaman yang akan ditanam ada yang bisa dipanen sampai dua bulan dan ada juga yang bisa dipanen lebih cepat

\section{Kreatifitas}

Tabel 17 menunjukkan bahwa sebagian besar responden, yaitu $16(53,33 \%)$ masyarakat di Kelurahan Teling Bawah Kota Manado sangat setuju, serta terdapat $14(46,67 \%)$ setuju bahwa Hidroponik dapat menumbuhkan kreativitas. Dalam indikator ini, total skor persepsi masyarakat sebesar $136 / 150$ x $100 \%$ $=90,67 \%$, sehingga interpretasi nilainya tergolong sangat setuju.

Tabel 17. Persepsi Masyarakat Terhadap Hidroponik Dapat Menumbuhkan Kreatifitas

\begin{tabular}{ccccc}
\hline $\begin{array}{c}\text { Alternatif } \\
\text { Jawaban }\end{array}$ & Skor & $\begin{array}{c}\text { Jumlah } \\
\text { Responden }\end{array}$ & $\begin{array}{c}\text { Persentase } \\
(\%)\end{array}$ & $\begin{array}{c}\text { Total } \\
\text { Skor }\end{array}$ \\
\hline Sangat & 5 & 16 & 53,33 & 80 \\
Setuju & 4 & 14 & 46,67 & 56 \\
Setuju & 4 & - & - & - \\
Ragu-Ragu & 3 & - & - & - \\
Tidak Setuju & 2 & - & - & - \\
$\begin{array}{c}\text { Sangat } \\
\text { Tidak Setuju }\end{array}$ & 1 & 30 & 100 & 136 \\
\hline Jumlah & & 3017
\end{tabular}

Sumber : Diolah dari data primer, 2017
Alasan yang dikemukakan oleh responden yamg menyatakan sangat setuju dan setuju bahwa Hidroponik dapat menumbuhkan kreatifitas adalah karena saat ini tipe Hidroponik sudah sangat banyak dan juga sudah muncul kreasi-kreasi baru sehingga orang akan tertarik untuk mencoba bercocok tanam dengan menggunakan teknik Hidroponik, dan hanya orang kreatif dan orang sabarlah yang bisa melakukan pertanian Hidroponik.

\section{Bebas Bencana Alam}

Tabel 18 menunjukkan bahwa sebagian besar responden, yaitu $13(43,34 \%)$ masyarakat di Kelurahan Teling Bawah Kota Manado setuju, serta terdapat $9(30,00 \%)$ sangat setuju, dan juga terdapat $6(20,00 \%)$ raguragu dan $3(6,67 \%)$ tidak setuju bahwa Hidroponik bebas bencana alam. Dalam indikator ini, total skor persepsi masyarakat sebesar $119 / 150 \times 100 \%=79,33 \%$, sehingga interpretasi nilainya tergolong setuju.

Tabel 18. Persepsi Masyarakat Terhadap Hidroponik Bebas Bencana Alam

\begin{tabular}{|c|c|c|c|c|}
\hline $\begin{array}{l}\text { Alternatif } \\
\text { Jawaban }\end{array}$ & Skor & $\begin{array}{c}\text { Jumlah } \\
\text { Responden }\end{array}$ & $\begin{array}{c}\text { Persentase } \\
(\%)\end{array}$ & $\begin{array}{l}\text { Total } \\
\text { Skor }\end{array}$ \\
\hline $\begin{array}{l}\text { Sangat } \\
\text { Setuju }\end{array}$ & 5 & 9 & 30,00 & 45 \\
\hline Setuju & 4 & 13 & 43,34 & 52 \\
\hline Ragu-Ragu & 3 & 6 & 20,00 & 18 \\
\hline Tidak Setuju & 2 & 2 & 6,67 & 4 \\
\hline $\begin{array}{l}\text { Sangat Tidak } \\
\text { Setuju }\end{array}$ & 1 & - & - & \\
\hline Jumlah & & 30 & 100 & 119 \\
\hline
\end{tabular}

Hal yang melatarbelakangi persepsi masyarakat sangat setuju dan setuju bahwa Hidroponik bebas bencana alam adalah karena Hidroponik tidak menggunakan tanah dan sangat mudah untuk dipindahkan jika terjadi bencana alam seperti banjir, sedangkan menurut responden yang ragu-ragu dan tidak setuju, alasannya bila tidak dikontrol dengan baik airnya, akan terjadi kekeringan sehingga akan berdampak buruk pada Hidroponik, jika Hidroponik dibuat tanpa menggunakan green 
house maka jika cuaca hujan akan juga sangat berdampak buruk bagi kualitas tanaman Hidroponik.

\section{Persepsi Dari Faktor Eksternal Baik untuk Kawasan Perkotaan}

Tabel 19 menunjukkan bahwa sebagian besar responden, yaitu $24(80,00 \%)$ masyarakat di Kelurahan Teling Bawah Kota Manado setuju, serta terdapat $6(20,00 \%)$ setuju. Dalam indikator ini, total skor persepsi masyarakat sebesar $144 / 150 \times 100 \%=96,00 \%$, sehingga interpretasi nilainya tergolong sangat setuju.

Tabel. 19. Persepsi Masyarakat Terhadap Hidroponik Baik Dikembangkan Untuk Kawasan Perkotaaan

\begin{tabular}{ccccc}
\hline $\begin{array}{c}\text { Alternatif } \\
\text { Jawaban }\end{array}$ & Skor & $\begin{array}{c}\text { Jumlah } \\
\text { Responden }\end{array}$ & $\begin{array}{c}\text { Persentase } \\
(\%)\end{array}$ & $\begin{array}{c}\text { Total } \\
\text { Skor }\end{array}$ \\
\hline Sangat & 5 & 24 & 80,00 & 120 \\
Setuju & & & & \\
Setuju & 4 & 6 & 20,00 & 24 \\
Ragu-Ragu & 3 & - & - & - \\
Tidak Setuju & 2 & - & - & - \\
$\begin{array}{c}\text { Sangat Tidak } \\
\text { Setuju }\end{array}$ & 1 & - & - & - \\
\hline Jumlah & & $\mathbf{3 0}$ & $\mathbf{1 0 0}$ & $\mathbf{1 4 4}$ \\
\hline
\end{tabular}

Sumber : Diolah dari data primer, 2017

Hal yang melatarbelakangi persepsi masyarakat sangat setuju dan setuju bahwa Hidroponik baik dikembangkan untuk kawasan perkotaan karena Hidroponik adalah salah satu bentuk urban farming atau teknik bercocok tanam yang memanfaatkan lahan kota, sehingga kota akan menjadi lebih hijau jika masyarakat kota melakukan pertanian Hidroponik dimasing-masing pekarangan rumah mereka.

\section{Agrowisata}

Tabel 20 menunjukkan bahwa sebagian besar responden, yaitu $16 \quad(53,33 \%)$ masyarakat di Kelurahan Teling Bawah Kota Manado setuju, serta terdapat $11(36,67 \%)$ sangat setuju ,terdapat juga $3(10,00 \%)$ yang ragu-ragu. Dalam indikator ini, total skor persepsi masyarakat sebesar 128/150 x 100\%
$=85,33 \%$, sehingga interpretasi nilainya tergolong sangat setuju.

Tabel 20. Persepsi Masyarakat Terhadap Hidroponik Dapat Dijadikan Agrowisata

\begin{tabular}{lcccc}
\hline $\begin{array}{l}\text { Alternatif } \\
\text { Jawaban }\end{array}$ & Skor & $\begin{array}{c}\text { Jumlah } \\
\text { Responden }\end{array}$ & $\begin{array}{c}\text { Persentase } \\
(\%)\end{array}$ & $\begin{array}{c}\text { Total } \\
\text { Skor }\end{array}$ \\
\hline Sangat & 5 & 11 & 36,67 & 55 \\
Setuju & & & & \\
Setuju & 4 & 16 & 53,33 & 64 \\
Ragu-Ragu & 3 & 3 & 10,00 & 9 \\
Tidak & 2 & - & - & - \\
Setuju & & & - & - \\
Sangat & 1 & - & & \\
Tidak & & & & \\
Setuju & & & & \\
\hline
\end{tabular}

\begin{tabular}{cccc}
\hline Jumlah & $\mathbf{3 0}$ & $\mathbf{1 0 0}$ & $\mathbf{1 2 8}$ \\
\hline Sumber : Diolah dari data primer, 2017 &
\end{tabular}

Hal yang melatarbelakangi persepsi masyarakat menyatakan sangat setuju dan setuju bahwa Hidroponik dapat dijadikan agrowisata karena keragaman jenis serta keindahan yang dimiliki oleh setiap tipe Hidroponik berbeda sehingga membuat wisatawan tertarik untuk melihat Hidroponik tersebut serta ingin mencoba untuk membuatnya. Sejalan dengan itu, saat ini Hidroponik di Kota Manado mulai diminati. Hal ini nampak dalam pameran-pameran di Kota Manado dan Bitung teknik pertanian Hidroponik diperkenalkan dan diperlihatkan. Sedangkan menurut responden yang raguragu, alasannya tergantung pada keberhasilan pembuatan Hidroponik tersebut. Hidroponik yang alat dan tanamannya tidak tertata dengan rapi dan baik maka tidak akan menarik minat untuk dilihat sehingga sebaiknya tidak ditunjukkan kepada orang-orang atau wisatawan.

\section{Total Persepsi Secara Keseluruhan}

Penilaian persepsi masyarakat

Kelurahan Teling Bawah Kota Manado terhadap Hidroponik secara keseluruhan dapat dilihat pada Tabel 21. 
Tabel 21. Hasil Rekapitulasi Penilaian Persepsi Masyarakat Terhadap Hidroponik Di Kelurahan Teling Bawah Kota Manado

\begin{tabular}{|c|c|c|c|c|}
\hline No & Variabel & Sub Variabel & Nilai & Keterangan \\
\hline \multirow[t]{2}{*}{1} & & Lahan & 134 & Sangat \\
\hline & & & & Setuju \\
\hline \multirow[t]{2}{*}{2} & & Higienitas & 131 & Sangat \\
\hline & & & & Setuju \\
\hline 3 & & Bebas Hama & 108 & Setuju \\
\hline \multirow[t]{2}{*}{4} & & Praktis & 126 & Sangat \\
\hline & & & & Setuju \\
\hline \multirow[t]{2}{*}{5} & Faktor & Banyak & 113 & Setuju \\
\hline & & Nutrisi & & \\
\hline \multirow[t]{2}{*}{6} & Internal & Kualitas & 126 & Sangat \\
\hline & & Sempurna & & Setuju \\
\hline \multirow[t]{2}{*}{7} & & Daur Ulang & 135 & Sangat \\
\hline & & & & Setuju \\
\hline \multirow[t]{3}{*}{8} & & Pertumbuhan & 115 & Setuju \\
\hline & & Tanaman & & \\
\hline & & Cepat & & \\
\hline \multirow[t]{2}{*}{9} & & Kreativitas & 136 & Sangat \\
\hline & & & & Setuju \\
\hline \multirow[t]{3}{*}{10} & & Bebas & 119 & Setuju \\
\hline & & Bencana Alam & & \\
\hline & & Jumlah & 1.243 & $\begin{array}{l}\text { Sangat } \\
\text { Setuju }\end{array}$ \\
\hline No & Variabel & Sub Variabel & Nilai & Keterangan \\
\hline \multirow[t]{3}{*}{1} & Faktor & Baik Untuk & 144 & Sangat \\
\hline & & Kawasan & & Setuju \\
\hline & & Perkotaan & & \\
\hline \multirow[t]{4}{*}{2} & Eksternal & Agrowisata & 128 & Sangat \\
\hline & & & & Setuju \\
\hline & & Jumlah & 272 & $\begin{array}{l}\text { Sangat } \\
\text { Setuju }\end{array}$ \\
\hline & & Total & 1.515 & $\begin{array}{l}\text { Sangat } \\
\text { Setuju }\end{array}$ \\
\hline
\end{tabular}

Sumber: Diolah dari data primer, 2017

Berdasarkan Tabel 21 dapat dilihat bahwa hasil penilaian responden terhadap persepsi masyarakat Kelurahan Teling Bawah Kota Manado secara keseluruhan adalah Sangat Setuju dengan total bobot 1.515. Penilaian dari variabel Faktor Internal dengan sub variabel yang meliputi lahan dengan bobot 134, Higienitas dengan bobot 131, Bebas hama dengan bobot 108, Kepraktisan dengan bobot 126, Banyak nutrisi dengan bobot 113, Kualitas sempurna dengan bobot 126, Daur ulang dengan bobot 135, Pertumbuhan tanaman cepat dengan bobot 115, Kreativitas dengan bobot 136, dan Bebas bencana alam dengan bobot 119. Dengan jumlah pada variabel Fakto Internal yaitu 1.243 yang berkategorikan Sangat Setuju. Penilaian pada Faktor Eksternal dengan sub-variabel yang meliputi Baik untuk kawasan perkotaan dengan bobot 144, dan Agrowisata dengan bobot 128 . Dengan jumlah pada variabel Faktor Eksternal yaitu 272 yang berkategorikan Sangat Setuju. Cara Perhitungan Skor secara keseluruhan untuk mengetahui persepsi masyarakat kelurahan Teling Bawah Kota Manado terhadap Hidroponik:

Jumlah Skor Seluruh Kriterium = Capaian Jumlah Skor x Jumlah Responden x Jumlah

Pertanyaan

$\mathrm{S} 5=5 \times 30=150 \times 12=1800$

$\mathrm{S} 4=4 \times 30=120 \times 12=1440$

$\mathrm{S} 3=3 \times 30=30 \times 12=1080$

$\mathrm{S} 2=2 \times 30=60 \times 12=720$

$\mathrm{S} 1=1 \times 30=30 \times 12=360$

Jumlah skor ideal untuk keseluruhan pertanyaan $=1800$ (Sangat Setuju), sedangkan jumlah skor terendah adalah 360 (Sangat Tidak Setuju) berdasarkan hasil pengolahan data, maka diperoleh total skor 1515. Untuk mendapatkan gambaran yang jelas mengenai persepsi secara keseluruhan.

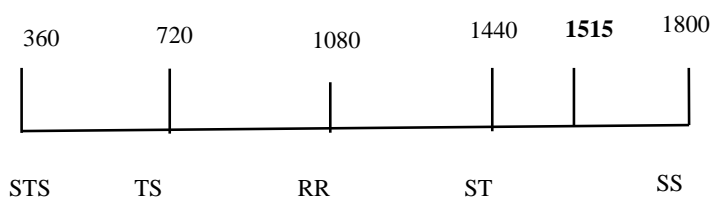

Keterangan :

SS = Sangat Setuju

ST $=$ Setuju

RG = Ragu-ragu

TS = Tidak Setuju

STS = Sangat Tidak Setuju

Jumlah skor sebanyak 1515 untuk persepsi masyarakat secara keseluruhan skor (10801800) yang berkategorikan Sangat Setuju. Hal ini menyatakan masyarakat di Kelurahan Teling Bawah Kota Manado Sangat Setuju dengan Pertanian Hidroponik karena masyarakat berpendapat dengan Hidroponik masyarakat dapat memproduksi sayuran sendiri yang sehat dirumah serta dapat meningkatkan penghijauan di daerah perkotaan. Melihat persepsi masyarakat yang sangat setuju terhadap pertanian Hidroponik maka dapat dikatakan bahwa menurut responden, Hidroponik sangat bermanfaat serta membawa dampak yang baik bagi masyarakat khususnya masyarakat perkotaan. Analisis yang digunakan merupakan analisis deskriptif yang dianalisis dengan menggunakan Skala Likert menurut, 
Riduwan (2008) dalam buku rumus dan data analisis statistika sebagai berikut:

Persepsi Masyarakat

$=\frac{\text { JumlahSkorHasilPengumpulanData }}{\text { JumlahSkorIdeal (Tertinggi) }} \times 100 \%$

Persepsi Masyarakat $=\frac{1515}{1800} \times 100 \%=84,16 \%$

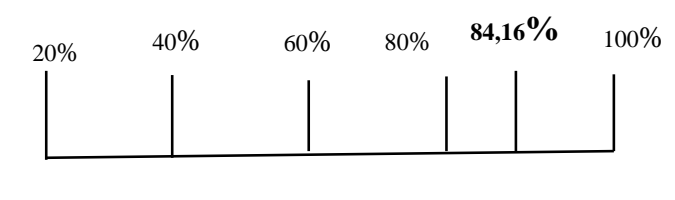

$\begin{array}{llllll}\text { STS } & \text { TS } & \text { RR } & S & \text { SS }\end{array}$

Skala Persepsi Masyarakat Terhadap Hidroponik Secara Keseluruhan Persentase. Berdasarkan hasil analisis menggunakan Skala Likert, maka dapat diketahui bahwa angka indeks persepsi masyarakat terhadap tanaman Hidroponik di Kelurahan Teling Bawah Kota Manado adalah sebesar 84,16\% dan tergolong dalam kategori Sangat Setuju. Hasil wawancara pada responden yang tinggal di Kelurahan Teling Bawah Kota Manado menunjukkan persepsi masyarakat terhadap Hidroponik sangat baik. Masyarakat sangat setuju dengan adanya teknik pertanian dengan menggunakan Hidroponik, masyarakat berpendapat bahwa Hidroponik sangat bermanfaat bagi masyarakat karena dengan Hidroponik maka masyarakat dapat mengkonsumsi buah dan sayur yang sehat tanpa menggunakan bahan-bahan kimia. Berdasarkan hasil wawancara dengan masyarakat di Kelurahan Teling Bawah Kota Manado manfaat Hidroponik menurut masyarakat yaitu tidak perlu bersusah payah mencari lahan untuk bercocok tanam, dapat memanfaatkan barangbarang bekas dirumah, tidak membutuhkan waktu yang lama untuk berhidroponik, dan tidak menggunakan tanah seperti pertanian konvensional sehingga pelaku Hidroponik tidak perlu bersentuhan dengan cacing. Responden juga memberikan saran agar Hidroponik harus lebih dikembangkan lagi khususnya di daerah perkotaan, responden juga menyarankan agar pemerintah dapat memberikan informasi lewat penyuluhan-penyuluhan tentang keuntungan Hidroponik kepada masyarakat yang belum mengetahui tentang Hidroponik serta menyediakan nutrisi Hidroponik yang cukup banyak bagi masyarakat yang melakukan pertanian Hidroponik.

\section{KESIMPULAN DAN SARAN}

\section{Kesimpulan}

Hasil penelitian persepsi masyarakat terhadap Hidroponik di Kelurahan Teling Bawah Kota Manado dapat dikategorikan Sangat Setuju. Hal ini menunjukkan bahwa masyarakat sangat menyukai pertanian Hidroponik. Mereka berpendapat bahwa Hidroponik sangat bermanfaat dan membawa dampak yang sangat baik bagi masyarakat.

\section{Saran}

Kiranya Hidroponik dapat lebih lagi dikembangkan di daerah perkotaan, kiranya pemerintah boleh membantu untuk meningkatkan pertanian Hidroponik lewat sosialisasi dan penyuluhan kepada masyarakat untuk bisa melakukan pertanian Hidroponik. Pemerintah Sulawesi Utara khususnya Kota Manado dapat menyediakan dan memproduksi nutrisi Hidroponik sendiri sehingga nutrisi Hidroponik dapat dibeli di Manado dan tidak lagi harus didapatkan dari di luar daerah.

\section{DAFTAR PUSTAKA}

Anisa, Febri, Leni, 2016. Urban Farming: Bertani Kreatif Sayur, Hias, Dan Buah. Jakarta. Agriflo

Berlin, S, 2015. Kupas Tuntas Hidroponik. Jakarta:Kata Pena

Ibrahim, MA, 2015. Metodologi Penelitian Kualitatif. Bandung:Alfabeta

Riduwan, 2003. Skala Pengukuran VariabelVariabel Penelitian. Surabaya:CV Alfabeta

Salikin, A, 2003. Sistem Pertanian Berkelanjutan. Yogyakarta: Kanisius

Sarwono, W, 2005. Psikologi umum. Jakarta:Bulan Bintang

Suryani, R, 2016. Hidroponik: Budidaya Tanaman Tanpa Tanah:Yogyakarta. Arcitra

Suharman, 2005. Psikologi Kognitif. Surabaya:Srikandi

Widyawati , N, 2013. Urban Farming- Gaya Bertani Spesifik Kota. Yogyakarta:Lily Publisher 